\title{
How do we live with chronic disease? A rights-based approach promoting the wellbeing of children with chronic disease
}

\author{
Como é que vivemos com doenças crônicas? Uma abordagem baseada \\ em direitos para promover o bem-estar de crianças com doenças \\ crônicas
}

Sofia Castanheira Pais (https://orcid.org/0000-0003-2841-9922) ${ }^{1}$

Isabel Menezes (https://orcid.org/0000-0001-9063-3773) ${ }^{1}$

${ }^{1}$ Centre for Research and Intervention in Education, Faculty of Psychology and Education Sciences, University of Porto. R. Alfredo Allen. 4200-135 Porto Portugal. sofiapais@fpce.up.pt

\begin{abstract}
This paper focuses on the life experiences of children with chronic disease, a group whose invisibility involves particular challenges in their relationship with professionals in important life contexts, such as family, school and hospital. The study includes two complementary phases: i) Phase 1, composed of 15 interviews with parents, education and health professionals and two focus group discussions with children, and children and their mothers; and ii) Phase 2, which included self-report questionnaires administered to parents $(n=152)$ and children with chronic disease $(n=176)$. Based on a mixed methodology, this study combines quantitative and qualitative methods assuming that plural approaches allow for a deeper understanding of the life conditions of children with chronic disease and their families. The results reinforce the reproduction of social stereotypes and the tendency to focus on the individual ability to solve problems, which still remain to be circumscribed to the people's chronic disease sphere. Moreover, this paper reveals the central role that inclusive contexts have on children's wellbeing.
\end{abstract}

Key words Chronic disease, Children, Wellbeing, Empowerment, Life contexts
Resumo Este artigo foca-se nas experiências de vida de crianças com doenças crônica, cuja invisibilidade envolve desafios particulares no que respeita à sua relação com profissionais, em importantes contextos de vida, como sejam a família, a escola e o hospital. Este estudo inclui duas fases complementares: i) Fase 1, composta por 15 entrevistas com pais, profissionais de educação e de saúde, e dois grupos de discussão focalizada com crianças e com crianças e suas mães; e ii) Fase 2, a qual inclui questionários autoadministrados a pais $(n=152)$ e a crianças com doença crônica ( $n=176)$. Baseado numa metodologia mista, este estudo combina métodos qualitativos e quantitativos, assumindo que abordagens plurais permitem um conhecimento mais aprofundado das condições de vida das crianças com doença crônica e suas famílias. Os resultados reforçam a reprodução de estereótipos sociais e a tendência para enfatizar a capacidade individual para resolver problemas, a qual parece estar ainda circunscrita à esfera das pessoas com doença crônica. Para além disso, este artigo revela o papel central que os contextos inclusivos têm no bem-estar das crianças. Palavras-chave Doença crônica, Crianças, Bem -estar, Empoderamento, Contextos de vida 


\section{Introduction}

This paper aims to address chronic disease experiences regarding their implications on children and family lives. Chronic illness is defined as "a disease of long duration and generally slow progression"'; its impacts are long-lasting and reflect not only on the individual but also on his/her social and familiar networks ${ }^{2,3}$. Given that length is one of the nuclear features of chronic illness - "a condition that lasts more than three months in a year or requiring a hospital stay for more than a month"4- it is not surprising that there is a consensus regarding three aspects: a) it involves adjustments in many fields of life; b) it builds up over time, requiring additional corrections associated with its development; and c) it is characterised by the heterogeneity in individual development combined with the singularity in the way in which each person fits into it ${ }^{5}$. Therefore, adaptation processes in chronic disease are not only continuous and durable, but also related to the different contexts in which individuals operate and move $e^{6,7}$, considering the specific characteristics inherent in the chronic disease.

The current list of Non-communicable diseases (NCD), also known as chronic diseases, includes "congenital conditions (eg, Down's syndrome and neural tube defects), degenerative conditions (prostatic hypertrophy, cataracts, and hearing loss), musculoskeletal problems (back pain, arthritis, gout), genitourinary conditions (infertility and kidney stones), mental health problems (depression, schizophrenia), and the 'big four' - cardiovascular disease, cancer, chronic respiratory disease, and type 2 diabetes"s. If, on one hand, there is a significate "variation in the diseases that are included under the umbrella term 'chronic disease' [, on the other hand, this] variation in the time a disease must be present for something to be referred to as chronic" might also be considered'. Based on Cohen and colleagues' framework, chronic conditions of childhood should consider four main domains: needs (eg. medical care, specialized therapy, and educational needs); chronic conditions (meaning the existence of chronic clinical conditions); functional limitations (meaning the interference of the disease in terms of function, performance and participation in daily activities); and health care use (eg. hospitalization, surgeries $)^{10}$. The combination of specific aspects of each of these domains includes the collective features of what these authors ${ }^{10}$ call Children with Medical Complexity (CMC). Considering that, both the severity and the invisibility of the diseases were defined as selection criteria to constitute the sample, meaning that diseases with moderated severity and that could not be immediately identified were incorporated in this study. Thus, only children older than 12 with asthma, arthritis, diabetes, epilepsy, heart and respiratory disease were included.

Literature shows that children with chronic diseases have to cope with developmental tasks and everyday stressors ${ }^{11-13}$. Moreover, "the type, consistency, and severity of functional limitations [imposed by the disease may also] vary over the life of the child in the context of environmental and personal factors" interfering determinately in his/her daily activities ${ }^{10}$. In this sense, despite the variability of impacts within the different diseases, chronic conditions in childhood can affect physical appearance and growth, resulting in reduced activity, pain, the need for regular therapy and sometimes unpleasant procedures, as well as the risk of social rejection and possible loss of schooling ${ }^{12,14}$. In fact, children suffering from chronic diseases tend to experience the effects of lost class time regarding their academic and social functioning, which poses a special concern for educators ${ }^{15}$. This frequently interferes with the child's psychosocial development ${ }^{16}$. Thus, some studies underlie the relationship between the risks for the child development and lower socio-economic groups of children, since they might be more vulnerable to the persistency of psychological maladaptation into adulthood ${ }^{17,18}$. Indeed, the number and proportion of children with disabling chronic conditions is unavoidably related to economic, social and cultural factors ${ }^{19}$. At this point, the increment of "quality chronic-illness care increasingly emphasizes social factors that can improve patient outcomes across most illness conditions"20.

In this sense, considering that the experience of living with a chronic disease may, in some instances severely, interfere in the development of children ${ }^{12,21}$ but also of their social network, the discussion on the manifestations and effects caused by this chronic condition must involve others in the promotion of wellbeing and empowerment of people with chronic disease ${ }^{22,23}$. So, this paper assumes the need to balance the subjective dimension and the contextual factors using Bronfenbrenner's ${ }^{24}$ ecological perspective. In fact, family, school, hospital and other socialising contexts gain the utmost importance in the everyday life of children beyond conventional challenges ${ }^{25}$. Thus, the inseparability of contexts affects the experience of individuals and conditions the (improvement of) quality of life $\mathrm{e}^{2,24,26}$. Ecological and clinical collaboration (between patient/ 
family and professionals) seems, therefore, to be a very relevant dimension in promoting people's health and wellbeing. Moreover, beyond clinical work, "even the most severe symptoms are [and might be] a family's best strategy for stability with their available resources"11.

Despite the variety of ways families find to manage this process, disease rhythms are conditioned by numerous variables, including personal resources, the specificity of the disease and the treatments, the quality of relationships with professionals, and so on ${ }^{11,27}$. Difficulties such as dealing with unpredictability over a long period of time or maintaining an identity that does not fully encompass the disease nor is completely consumed by it are experienced by parents of children with chronic disease $\mathrm{e}^{26,28}$. Moreover, since their main goal is the promotion of welfare conditions to their children, experiencing multiple roles becomes a frequent activity. Being caretakers in many senses, they act in several contexts and negotiate with different professionals whose practices might contribute to their children's wellbeing ${ }^{27}$.

Assuming the barriers imposed by health conditions, there are other constraints with strong impact on people with chronic illness. Once the importance of reconfiguring health and health policy becomes recognised, it is indeed necessary to contextualise in social and political terms the experience of living with a chronic disease. This implies a shift towards rights rather than needs in people's experiences ${ }^{29}$, recognising children with chronic disease and their families first and foremost as citizens who are able to intervene and to participate in the decisions that affect their lives ${ }^{30}$. Nevertheless, admitting that traditionally paternalistic models still prevail in the discussion of chronic disease $e^{31}$, we consider that the concept of empowerment is central in this debate, "since it involves the recognition of cultural practices, social and political citizenship that are experienced by different groups of people in different national contexts" ${ }^{\prime \prime 2}$. Thus, empowerment is the process by which individuals, organisations and communities gain control over their lives and ensure democratic participation in the life of their communities $^{33,34}$. Furthermore, the definition of empowerment by Zimmerman ${ }^{35}$ relates clearly to the analysis of the concept at an individual level. However, it does not make sense to circumscribe people with chronic disease to a domain that tends to be viewed individually and closed ${ }^{33}$.

So, this paper focuses on the implications of having chronic diseases in children's and their families' daily activities assuming a rights-based approach. Wellbeing is a central variable for the analysis of these children's and their parents' life experiences. Contexts such as family, school and hospital are analysed, considering their effects on people's empowerment and wellbeing promotion.

\section{Methods}

The research design is based on methodological hybridism, admitting that plural approaches allow a deeper understanding ${ }^{36,37}$ of these children's and their families' life conditions. Data were collected in Portugal using mixed methods in two complementary phases, considering that this might result in a broader and more legitimate knowledge $^{38}$.

Phase 1 involved a qualitative process and focused on the analysis of chronic disease experiences in family, school and hospital settings, considering children's difficulties and strategies in these nuclear life contexts. This phase was composed of i) 5 interviews with parents (four mothers and one father), and ii) two focus group discussions with children (three participants), their mothers (three children and their mothers, so six participants). All parents lived in the North of the country and their children, aged between 8 and 12, have chronic diseases, such as diabetes, arthritis and asthma. The sample was defined for convenience, ensuring that only families and children with these chronic conditions would be included. The interviews were conducted at their homes or locations that were convenient for both the participants and the researcher, such as the workplace (after office hours) or the researcher's higher education institution. The focus group discussions with children and with children and their mothers took place at the house of one of the mothers of the children's group, once the participants were well-known to each other.

During phase 1 it was important to listen children with chronic diseases talking about their own experiences, recognising that they can be involved in the research processes ${ }^{39}$. Focus group discussions were very important in this process since they allowed access to a shared knowledge among group members in what concerns their perspectives of chronic disease and citizenship issues. Children's participation in focus group discussions was authorised by their parents and the conditions of confidentiality and anonymity were assured.

Data analysis for the qualitative phase was based on content analysis. This "set of methodological tools, increasingly subtle, constantly improving, that apply to extremely diverse 'dis- 
courses" "40 seemed to be an adequate technique to put into perspective so many different visions among chronic disease experiences. In this paper, we will present an overview of the main results of phase 1 , emphasising both difficulties and strategies in family, school and hospital contexts.

Phase 2 focused on exploring relevant models and predictors of wellbeing of children with chronic disease using self-report questionnaires administered to parents $(n=152)$ and children (older than 12, in order to be able to answer the questionnaire autonomously) $(n=176)$. The two versions of the instrument included scales on autonomy, wellbeing, satisfaction with life contexts (hospital, school), school integration and empowerment. The completion of the questionnaire took approximately 20 minutes and it usually happened before the medical appointment. Despite the fact that questionnaires were self-administrated, authors of this paper were always present to introduce the questionnaire and clarify possible questions. Almost all questionnaires were administered in hospitals but, to a lesser degree, also through support associations. The sample of chronic diseases included asthma, arthritis, diabetes, epilepsy, heart and respiratory disease and only children older than 12 with these chronic conditions were included in the study. Despite recognising the existence of several other chronic diseases, such as Cerebral Palsy, with intensive care needs that are not easily met by various professionals, authors defined the sample considering two criteria. On one hand, the severity of the diseases had to be moderate and, on the other hand, the diseases could not be immediately identified, meaning that invisibility was an important characteristic of all the diseases included in the sample. This study was approved by Ethics Committee of the hospitals involved in the research process and a file number was generated and attached to such proceedings. All participants (including adults and children) agreed to take part in the study and gave their written informed consent.

Data analysis was performed using the Statistical Package for the Social Sciences (SPSS), version 18, and the Analysis of Moment Structures (AMOS) software. Confirmatory factor analysis was conducted in order to test the dimensionality of the questionnaire and the adjustment of the data to the theoretical models both for the parents and the children's versions ${ }^{41}$; in both cases results showed an adequate fit and reliability of the measures. The scales included the following scales and dimensions as shown in Table 1.

In this paper, results of both phase 1 and 2 focus on the chronic disease experience regarding children's and parents' main challenges among life contexts and professionals. The wellbeing of children with chronic disease is the major variable analysed in this study. Regarding the importance of individual variables as predictors of the children's wellbeing in this study, linear regression includes satisfaction with life contexts, the origin of the disease, the existence of experiences of discrimination and empowerment variables.

\section{Results}

\section{Phase 1. The experience of chronic disease regarding the main life contexts}

Living with a chronic disease includes unavoidably a multiplicity of contexts and challenges. Qualitative data reveal that the wellbeing of children with chronic disease and their families are conditioned by the quality of those contexts' experiences. In this sense, all parents referred in their interviews several adaptations that they experienced regarding their child's health conditions. The sample of children of this study is characterised by none having congenital diseases. As mother A said:

At the beginning it was very difficult to manage all the family rhythms. I have two more children and taking into account the medication, food specificities and so on was a hard task. But after a while, it became a natural routine.

Besides, the relationship between the existence of a visible chronic condition and having an equal treatment regarding those who do not have any chronic disease has been shared by some more parents. In this sense, the recognition of special needs seems to be, in some way, camouflaged. And it might happen due to the prevalence of social stereotypes, as Father C explained:

I am absolutely convinced that, if my son [with diabetes] had a visible chronic condition, he would be an easy target. And I mean: discrimination attitudes from people around him.

The idea of "not being different" from the others, meaning the inexistence of a visible chronic condition, seems to work in a double sense for parents. If, on the one hand, it might be a way of avoiding exclusion and marginalisation attitudes, on the other hand, it does not allow for a right approach. Thus, the adjustments to the new "family member" have been felt by most families in social, economic and physical domains, as well as in different life contexts.

In the school setting, qualitative data reveal that this context might be one in which children 
Table 1. Scales and items.

\begin{tabular}{|c|c|c|}
\hline \multirow{7}{*}{$\begin{array}{l}\text { Wellbeing adapted from } \\
\text { the European Social } \\
\text { Survey [46] scales, with } \\
\text { two dimensions }\end{array}$} & Parents $\left[\chi^{2}(40)=76.478\right.$, & Social wellbeing \\
\hline & $\mathrm{p}<.000 ; \mathrm{CFI}=0.957$ & I feel that people respect my child' disease \\
\hline & \multirow{5}{*}{$\begin{array}{l}\text { Children }\left[\chi^{2} 43\right)=65.54 \\
\mathrm{p}<.015 ; \text { CFI }=0.95 ; \\
\text { RMSEA }=0.053]\end{array}$} & I feel that people respect my disease \\
\hline & & Personal wellbeing \\
\hline & & I feel that I am free to decide for myself how to live my \\
\hline & & life and conduct my child' health \\
\hline & & $\begin{array}{l}\text { I feel I am free to decide for myself how to live my life } \\
\text { and conduct my health }\end{array}$ \\
\hline $\begin{array}{l}\text { School integration } \\
\text { adapted from CIF, }\end{array}$ & $\begin{array}{l}\text { Children }\left[\chi^{2}(8)=9.840\right. \\
\mathrm{p}<.276 ; \text { CFI }=.994\end{array}$ & $\begin{array}{l}\text { I was always involved in school activities with peers and } \\
\text { teachers }\end{array}$ \\
\hline Simmeonson, 2006 & RMSEA $=0.035]$ & $\begin{array}{l}\text { I have always been able to do activities in order to } \\
\text { maintain my participation in school }\end{array}$ \\
\hline $\begin{array}{l}\text { Satisfaction with life } \\
\text { contexts adapted from }\end{array}$ & $\begin{array}{l}\text { Parents }\left[\chi^{2}(5)=2.32\right. \\
\mathrm{p}<.803 ; \mathrm{CFI}=1.000\end{array}$ & I'm satisfied with access to health care \\
\hline $\begin{array}{l}\text { WHOQOL-BREF, OMS, } \\
2004 \text { and the Quality }\end{array}$ & RMSEA $=0.000]$ & $\begin{array}{l}\text { The hospital appointments are scheduled for times when } \\
\text { I do not have classes or tests }\end{array}$ \\
\hline $\begin{array}{l}\text { of Life Index of Ferrans } \\
\text { and Powers, } 1984\end{array}$ & $\begin{array}{l}\text { Children }\left[\chi^{2}(9)=18.93\right. \\
\mathrm{p}<.026 ; \text { CFI }=0.97 \\
\text { RMSEA }=0.077]\end{array}$ & \\
\hline \multirow{6}{*}{$\begin{array}{l}\text { Empowerment, a scale } \\
\text { constructed for this } \\
\text { study [47], including } \\
\text { three dimensions }\end{array}$} & Parents $\left[\chi^{2}(109)=\right.$ & Interactional empowerment \\
\hline & $\begin{array}{l}236.728, \mathrm{p}<.000 ; \mathrm{CFI}= \\
0.908 ; \mathrm{RMSEA}=0.064]\end{array}$ & $\begin{array}{l}\text { Health policies have better results if people with a chronic } \\
\text { illness are involved in them }\end{array}$ \\
\hline & \multirow{4}{*}{$\begin{array}{l}\text { Children }\left[\chi^{2}(32)=48.88,\right. \\
\mathrm{p}<.029 ; \text { CFI }=0.94 ; \\
\text { RMSEA }=0.053]\end{array}$} & Self-centred behavioural empowerment \\
\hline & & $\begin{array}{l}\text { I can choose another health professional to follow my } \\
\text { child' health }\end{array}$ \\
\hline & & Hetero-centred behavioural empowerment \\
\hline & & $\begin{array}{l}\text { I helped other people overcome problematic situations } \\
\text { related to their disease }\end{array}$ \\
\hline
\end{tabular}

have both successful and disastrous experiences. In fact, if, on the one hand, school is for all, on the other hand, it seems to exclude some when it promotes generalised practices. Therefore, the difficulties reported by both children and their parents were based on inadequacy and discrimination episodes regarding their health condition. Sometimes, children with chronic disease are not allowed to get involved in the same tasks as their peers, while in other situations they have to do exactly the same that the others do. Nevertheless, the main question is that there are situations in which children with chronic disease feel that their teachers do not know how to act:

I believe that my teacher finds difficulties in managing activities with me, since she seems to have mixed feelings when she asks me to do things. This already happened when she didn't allow me to do simple things and when, in contrast, she thought that I should perform like my colleagues. (Children A). 
on the one hand, it seems to be a hostile place "where we see the suffering of others and particularly our children's pain" (Mother B), on the other hand, it "looks like a second home" (Mother D). So, in parents' description of the hospital context the following idea emerges:

Even though we don't like to be in the hospital, my daughter and I are sure that it is where we will find a solution to our problems. Hospital can take my child's pain away. (Mother E)

Sometimes we feel it is too much but hospital staff doesn't let us quit. It is almost the place where we belong. (Mother B)

In fact, the focus group discussions also reveal how important the hospital is in promoting children's self-confidence and wellbeing. Health professionals are quite essential in ensuring these two dimensions, as well as in making the difference in how families learn to cope with their children at home.

For me, my doctor is almost my best friend. I tell him everything about my diabetes and I even do some tricks. (Child B)

On the whole, the discourse of both children and parents reveal that the relationship with health and education professionals is important in the life experience with chronic disease.

\section{Phase 2. Relevant models and predictors regarding the wellbeing of children with chronic disease}

In order to understand which variables contribute most heavily to predicting the wellbeing of children with chronic disease, a linear regression was performed. In this analysis, beyond children's perceptions, their parents' perceptions were also included, since the way parents deal with their children's disease can be an important predictor of their children's wellbeing. The predictors were introduced in blocks, namely: 1) age and sex; 2) experiences of discrimination and origin of the disease (congenital or acquired); 3) satisfaction with health status, school integration, self-centred behavioural empowerment, interactional empowerment, hetero-centred behavioural empowerment and satisfaction with life contexts; 4) variables related to parents, namely social and personal wellbeing, satisfaction with contexts, and self-centred behavioural empowerment, hetero-centred behavioural empowerment and interactional empowerment.

First of all, 116 (76\%) from the total number of parents' respondents were female and the majority of women was married (79.9\%). The sample of children in this study included 95 (54\%) girls and $81(46 \%)$ boys and the mean age was 15.53 (with a standard deviation of 2.921). The majority of children were students $(95.4 \%)$. As can be seen in Table 2, the value of R2 corresponds to 0.469 , which allows concluding that all these variables explain, in a substantial way, the wellbeing of the children. If the experiences of discrimination and the origin of the disease congenital or acquired - seem to be relevant, it is, in fact, the introduction of satisfaction with health status, integration into school, self-centred behavioural empowerment, interactional empowerment, hetero-centred behavioural empowerment and satisfaction with the contexts of life that denotes a significant increase in the value of the explained variance. With less evidence, the variables related to the parents also contribute to increasing the explained variance.

Considering Table 3, given the role of individual variables as predictors of the children's wellbeing in this study, it is essentially satisfaction with life contexts that predict more significantly both children's and parents' wellbeing. Table 3 also reveals that the origin of the disease seems

Table 2. Results (Summary Model).

\begin{tabular}{|c|c|c|c|c|c|c|c|c|c|}
\hline \multirow{2}{*}{ Model } & \multirow{2}{*}{$\mathbf{R}$} & \multirow{2}{*}{$\begin{array}{c}\mathbf{R} \\
\text { Square }\end{array}$} & \multirow{2}{*}{$\begin{array}{l}\text { Adjusted } \\
\text { R. Square }\end{array}$} & \multirow{2}{*}{$\begin{array}{l}\text { Std. Error of } \\
\text { the Estimastes }\end{array}$} & \multicolumn{5}{|c|}{ Change Statistics } \\
\hline & & & & & R Change & F Change & df1 & df2 & Sig. F Change \\
\hline 1 & ,192a & ,037 & ,019 & ,58689 & ,037 & 2,094 & 2 & 109 & ,128 \\
\hline 2 & ,361b & ,130 & ,098 & ,56294 & ,093 & 5,737 & 2 & 107 &, 004 \\
\hline 3 &, $654 c$ & ,428 & ,371 & , 46991 & ,298 & 8,760 & 6 & 101 & ,000 \\
\hline 4 & ,685d & ,469 & ,380 & , 46667 & 041 & 1,234 & 6 & 95 & ,296 \\
\hline
\end{tabular}

a. Predictors: (Constant), Age, Gender. b. Predictors: (Constant), Age, Gender, Discrimination, Origin of the disease. c. Predictors: (Constant), Age, Gender, Discrimination, Origin of the disease, Satisfaction with health status, School Integration, Self-behavioural Empowerment, Interactional Empowerment, Hetero-behaviour Empowerment, Satisfaction with life contexts. d. Predictors: (Constant), Age, Gender, Discrimination, Origin of the disease, Satisfaction with health status, School Integration, Self-behavioural Empowerment, Interactional Empowerment, Hetero-behaviour Empowerment, Satisfaction with life contexts, Parents' interactional Empowerment, Parents' Social Wellbeing, Parents' self-behavioural Empowerment, Parents' personal wellbeing, Parents' hetero-behavioural Empowerment, Parents' satisfaction with life contexts. 
to be related to wellbeing, meaning that the congenital origin might contribute to children's wellbeing. This reinforces the idea that the process of adaptation inherent in the diagnosis phase, in the case of acquired disease, usually involves several difficulties for both children and their families. The existence of experiences of discrimination felt by children with chronic disease also seems to be related to their wellbeing. That is, feeling integrated, respected, recognised by their peers certainly has implications in wellbeing. Interactional empowerment and self-centred behavioural empowerment of children in this study are also associated with their wellbeing. In other words, opportunities for participation and access in many dimensions, as well as effective intervention for better living and health conditions, also contribute to the wellbeing of children with chronic conditions. Finally, parents' satisfaction with life contexts is a significant predictor of the

Table 3. Regression analysis summary.

\begin{tabular}{|c|c|c|c|c|c|c|}
\hline & \multirow[t]{2}{*}{ Model } & \multicolumn{2}{|c|}{$\begin{array}{c}\text { Unstandardized } \\
\text { Coefficients }\end{array}$} & \multirow{2}{*}{$\begin{array}{c}\text { Standardized } \\
\text { Coefficients }\end{array}$} & \multirow[t]{2}{*}{$\mathbf{t}$} & \multirow[t]{2}{*}{ Sig. } \\
\hline & & B & Std. Error & & & \\
\hline \multirow[t]{3}{*}{1} & (Constant) & 4,419 & ,353 & & 12,502 & ,000 \\
\hline & Sex (male) &, 039 &, 114 &, 033 & ,341 & ,734 \\
\hline & Age &,- 041 &, 022 &,- 182 & $-1,891$ & ,061 \\
\hline \multirow[t]{5}{*}{2} & (Constant) & 4,524 & ,341 & & 13,262 &, 000 \\
\hline & Sex (male) &,- 008 &, 110 &,- 007 &,- 072 & ,942 \\
\hline & Age &,- 044 &, 021 &,- 193 & $-2,062$ & 042 \\
\hline & Origin of the disease (congenital) & ,318 & ,159 & ,183 & 2,000 & ,048 \\
\hline & Experiences of Discrimination &,- 370 & ,128 &,- 265 & $-2,901$ & ,005 \\
\hline \multirow[t]{11}{*}{3} & (Constant) & 1,637 &, 547 & & 2,992 & ,003 \\
\hline & Sex (male) &,- 055 & ,096 &,- 046 &,- 570 &, 570 \\
\hline & Age &,- 038 &, 018 &,- 168 & $-2,124$ & ,036 \\
\hline & Origin of the disease (congenital) & ,181 &, 140 & ,104 & 1,291 & ,200 \\
\hline & Experiences of Discrimination &,- 223 &, 112 &,- 160 & $-1,994$ & 049 \\
\hline & School Integration &, 164 & 089 &, 161 & 1,850 & ,067 \\
\hline & Satisfaction with health status &,- 007 & ,078 &,- 007 &,- 086 & ,931 \\
\hline & Satisfaction with life contexts & ,235 &, 074 & ,285 & 3,175 & ,002 \\
\hline & Interactional Empowerment &, 170 &, 066 &, 214 & 2,587 & ,011 \\
\hline & Self-centred behavioural Empowerment & ,128 &, 052 & ,201 & 2,457 & ,016 \\
\hline & Hetero-centred behavioural Empowerment & ,045 & ,046 &, 081 & ,980 & ,329 \\
\hline \multirow[t]{17}{*}{4} & (Constant) & 1,636 & ,659 & & 2,484 & 015 \\
\hline & Sex (male) &,- 065 & , 100 &,- 055 &,- 650 &, 517 \\
\hline & Age &,- 036 & 018 &,- 158 & $-1,928$ & ,057 \\
\hline & Origin of the disease (congenital) &, 172 &, 140 & 099 & 1,226 & ,223 \\
\hline & Experiences of Discrimination &,- 238 &, 114 &,- 170 & $-2,089$ & ,039 \\
\hline & School Integration &, 183 & ,090 & ,179 & 2,031 & ,045 \\
\hline & Satisfaction with health status &,- 052 &, 080 &,- 053 &,- 647 &, 519 \\
\hline & Satisfaction with life contexts & ,219 & 075 & ,266 & 2,919 & ,004 \\
\hline & Interactional Empowerment &, 154 &, 069 & ,194 & 2,234 & ,028 \\
\hline & Self-centred behavioural Empowerment & ,151 & ,055 & ,237 & 2,729 & ,008 \\
\hline & Hetero-centred behavioural Empowerment &, 062 & ,049 &, 113 & 1,273 & ,206 \\
\hline & Parents' Social Wellbeing &, 020 & ,073 & ,025 & ,276 & ,783 \\
\hline & Parents' Personal Wellbeing &,- 120 & ,080 &,- 136 & $-1,505$ & ,136 \\
\hline & Parents' Satisfaction with life contexts & ,188 & ,088 & ,199 & 2,141 & ,035 \\
\hline & Parents'self-centred behavioural Empowerment &,- 066 &, 047 &,- 124 & $-1,415$ &, 160 \\
\hline & Parents' hetero-centred behavioural Empowerment &, 009 &, 060 &, 014 & ,152 & ,880 \\
\hline & Parents' Interactional Empowerment &,- 046 & ,059 &,- 069 &,- 784 & ,435 \\
\hline
\end{tabular}

a. Dependent Variable: Children's wellbeing. 
wellbeing of their children with chronic disease. Thus, the parents' relationship with professionals from important contexts, such as those where their children move in their daily life activities, seems to have a positive impact on the promotion of wellbeing.

\section{Discussion}

In general, results from both phases reveal that children with chronic diseases, as well as their families, are resilient in what concerns the difficulties they face in their daily lives. As phase 1 reveals, although the diversity of experiences regarding problematic situations that both children and families have to solve, their discourse seems to express gratitude and appeasement. In line with previous studies ${ }^{29,42}$, this relates to the invisibility of the disease - "Not having an exterior sign (...) apparently facilitates our lives" and the "exception" criteria, and results also from personal resources identification and individual mobilisation, in particular by parents. Nevertheless, it unavoidably highlights two main aspects: the reproduction of social stereotypes and the evident tendency to focus on individual ability to solve problems that still remain to be circumscribed to the people's chronic disease sphere ${ }^{43,44}$. Hence, in phase 1, the existence of a needs perspective over a rights perspective becomes clear even when parents admit that their children are lucky because their teachers seemed to be rigorously selected. So, it reveals that public institutions still focus on the responsibility for ensuring the wellbeing of individuals who invariably are in vulnerable conditions $s^{32,42}$. Furthermore, having a chronic disease or a specific health condition is not yet a plural and collective matter ${ }^{23,32}$, which results in a tendency for blaming the victim ${ }^{45}$.

The relationship with professionals seems to be a nuclear dimension to ensure the wellbeing of children with chronic disease. If, on the one hand, this study reveals that professionals might disseminate a set of inappropriate practices with disempowerment effects, on the other hand, these professionals are, themselves, reference figures who are extremely important in the promotion of both children's and parents' wellbeing. So, while sometimes characterised by misinformation and/or bureaucracy, it is expected that the relationships with professionals would be based on trust and empathy, with special importance for people with chronic disease experiences ${ }^{46}$.

In this sense, both educational and health professionals contribute significantly to the pro- motion of children's and parents' wellbeing as phase 1 reveals. This study reinforces the idea that parents are engaged in multiple tasks aiming to protect their children's rights. Moreover, it highlights the parents' role as mediators of the relationships between several contexts and professionals. Furthermore, data from phase 2 reveal that parents' satisfaction with life contexts is a significant predictor of the wellbeing of their children with chronic disease. The results also suggest the parents' role as caretakers, since they manage a variety of activities, expectations and practices that make the difference on the way their children are treated (meaning that it is still necessary to make a set of changes in order to guarantee their rights $)^{42,47}$. On the whole, results of this study suggest the importance of a perspective beyond the individual ${ }^{38}$, as well as the urgency of a vision of people's rights rather than needs ${ }^{34}$. Furthermore, this paper reinforces the relevance of a political discussion that recognises people with chronic disease as citizens ${ }^{32,48}$ that are autonomous to conduct their own lives: they are, in fact, active agents in managing their disease.

\section{Conclusion}

This study focuses on the life experiences of children with chronic disease considering their relationship with professionals. It reveals the importance of life contexts to promote these children' wellbeing, although it stresses that parents are still the main players in ensuring their children's rights. In this line, the relationship with health and educational professionals also constitutes for both children and parents a relevant aspect, since these professionals' discourses and practices have profound impact in their daily experiences.

Admitting that the criteria adopted to select the diseases were based on both the severity and the invisibility of the diseases, the sample of this study constitutes a limitation since it would be interesting to explore other chronic conditions' experiences. Likewise, despite having been recently published a chapter in which the involvement of professionals is nuclear to discuss several aspects that might contribute or hinder the wellbeing of children with chronic disease $\mathrm{e}^{22}$, the absence of their perspective in this paper is a limitation. This means that listening their own voices about the implications of chronic disease would likely reinforce the idea of a collective effort to promote children with chronic disease wellbeing.

Nevertheless, this study contributes to analyse health and educational professionals' roles in 
promoting children with chronic disease wellbeing. Thus, since they should be committed with meaningful and intentional strategies of coping with children, mainly those with particular health conditions, thinking on how to improve training courses for them should be a priority. These professionals' attitudes, especially in schools and hospital, are nuclear to the recognition of children's agency, and that is the reason why it should be of concern. Moreover, the maintenance of individualistic and paternalistic modes of interaction, through the main life contexts (family, school and hospital) might hinder the effective inclusion and wellbeing of children with chronic disease and their families.

Recognising that exploring the implications of chronic conditions in children's daily activities is very important to deeply understand how they live we believe that this study is constructive in two ways. If, on one hand, it adds to the underlying knowledge on what are these children and their families both difficulties and strategies, and, on the other hand, it highlights the importance of bringing this theme to the public sphere, claiming for a collective discussion based on rights rather than needs.

\section{Collaborations}

SC Pais worked on the research and methodology and I Menezes worked on final editing.

\section{Acknowledgments}

The authors wish to acknowledge the participants for their involvement in the research.

This work was supported by the Portuguese Foundation for Science and Technology (FCT) and by the European Social Fund, under the $\mathrm{Hu}$ man Capital Operational Programme (POCH) from Portugal 2020 Programme.

This work was also funded (in part) by National Funds through the FCT - Fundação para a Ciência e a Tecnologia (Portuguese Foundation for Science and Technology), within the strategic project of CIIE, with the ref. "UID/ CED/00167/2013" and within the strategic project of CES “UID/SOC/50012/2013”.

\section{References}

1. World Health Organization (WHO). Global Status Report on Noncommunicable Diseases 2010: description of the global burden of NCDs, their risk factors and determinants. Geneva: WHO; 2010.

2. Barlow JH, Shaw KL, Harrison K. Consulting the 'experts': children's and parents' perceptions of psycho-educational interventions in the context of juvenile chronic arthritis. Health Education Research 1999; 14(5):597-610

3. Mássimo E, Souza H, Freitas MI. Chronic non-communicable diseases, risk and health promotion: social construction of Vigitel participants. Cien Saude Colet 2015; 20(3):679-688.

4. Vieira MA, Lima R. Crianças e adolescentes com doença crónica: convivendo com mudanças. Revista Latino-Americana de Enfermagem 2002; 10(4):552-560.

5. Stanton A, Revenson T, Tennen H. Health psychology: psychological adjustment to chronic disease. Annual Review of Psychology 2007; 58:565-592.

6. Barros L. Psicologia Pediátrica. Perspectiva Desenvolvimentista. Lisboa: Climepsi Editores; 2003.

7. Boekaerts M, Roder I. Stress, coping, and adjustment in children with a chronic disease: a review of the literature. Disability and Rehabilitation 1999; 21(7):311-337.

8. Allen LN, Feigl AB. Reframing non-communicable diseases as socially transmitted conditions. Lancet Global Health 2017; 5:e644-e64.

9. Bernell S, Howard SW. Use Your Words Carefully: What Is a Chronic Disease? Frontiers in Public Health 2016; 4:159.

10. Cohen E, Kuo DZ, Agrawal R, Berry JG, Bhagat SKM, Simon TD, Srivastava R. Children with medical complexity: an emerging population for clinical and research initiatives. Pediatrics 2011; 127(3):529-538.

11. Barlow JH, Ellard DR. Psycho-educational interventions for children with chronic disease, parents and siblings: an overview of the research evidence base. Child Care Health Dev 2004; 30(6):637-645.

12. Boekaerts M, Roder I. Stress, coping, and adjustment in children with a chronic disease: a review of the literature. Disabil Rehabil 1999; 21(7):311-337. 
13. Hampel P, Rudolph H, Stachow R, Lab-Lentzsch A, Petermann F. Coping among children and adolescents with chronic illness. Anxiety, Stress, and Coping 2005; 18(2):145-155.

14. Beattie PE, Lewis-Jones MS. A comparative study of impairment of quality of life in children with skin disease and children with other chronic childhood diseases. British Journal of Dermatology 2006; 155:145151.

15. Bray M, Kehl T, Grigerick S, Loftus S, Nicholson H. Children with asthma: assessment and treatment in school settings. Psychology in the Schools 2008; 45(1):63-73.

16. Power C, Li L, Manor O. A prospective study of limiting longstanding illness in early adulthood. Int J Epidemiol 2000; 29(1):131-139.

17. Pless IB, Power C, Peckkam CS. Long term sequelae of chronic conditions in childhood. Paediatrics 1993; 91:1131-1136.

18. Silver EJ, Stein RE. Access to care, unmet health needs, and poverty status among children with and without chronic conditions. Ambul Pediatr 2001; 1(6):314320.

19. Newachec PW. Prevalence and impact of disabling chronic conditions in childhood. Am J Public Health 1998; 88(4):610-617.

20. Shapiro E. Chronic illness as a family process: a social-developmental approach to promoting resilience. Psychotherapy in Practice 2002; 58(11):1375-1384.

21. Shaw S, MacCabe P. Hospital-to-school transition for children with chronic illness: meeting the new challenges of an evolving health care system. Psychol Sch 2008; 45(1):74-87.

22. Pais SC. Crianças com doença crónica na escola e os desafios para o desenvolvimento profissional dos professores. In: Macedo E, Menezes I, organizadores. Currículo, política e cultura: Intercâmbios entre Brasil e Portugal. Curitiba: CRV; 2019. p. 111-130.

23. Moreira M, Gomes R, Sá M. Doenças crónicas em crianças e adolescentes: Uma revisão bibliográfica. Cien Saude Colet 2014; 19(7):2083-2094.

24. Bronfenbrenner U. The Ecology of Human Development. Harvard: Harvard Press; 1979.

25. Carpenter J, McConkey R. Disabled children's voices: The nature and role of future empirical enquiry. Children \& Society 2012; 26(3):251-261.

26. Fergunson P. A place in the family: an historical interpretation of research on parental reactions to having a child with a disability. The Journal of Special Education 2002; 36(3):124-147.

27. Alstchuler J. Working with Chronic Illness. New York: Palgrave, 1997.

28. Viana V, Barbosa M, Guimarães J. Doença crônica na criança: factores familiares e qualidade de vida. Psicologia, Saúde \& Doenças 2007; 8(1):117-127.

29. Pais SC, Guedes M, Menezes I. The values of empowerment and citizenship and the experience of children and adolescent with a chronic disease. Citizenship, Social and Economics Education 2012; 11(2):133-144.

30. Lister R. Inclusive citizenship: realizing the potential. Citizenship Studies 2007; 11(1):49-61.

31. Barnes C. Disability activism and the struggle for change: disability, policy and politics in the UK. $E d-$ ucation, Citizenship and Social Justice 2007; 2(3):203221.
32. Lister R. Young people talk about citizenship: empirical perspectives on theoretical and political debates. Citizenship Studies 2003; 7(2):235-253.

33. Rappaport J. In praise of paradox: a social policy of empowerment over prevention. American Journal of Community Psychology 1981; 9(1):1-25.

34. Trickett EJ. Community psychology: Individuals and interventions in community contexts. Annu Rev Psychol 2009; 60:395-419.

35. Zimmerman MA. Psychological empowerment: issues and illustrations. American Journal of Community Psychology 1995; 23(5):581-599.

36. Grenne JC, Kreider H, Mayer E. Combining qualitative and quantitative methods in social injury. In: Somekn B, Lewin C, editors. Research Methods in the Social Sciences. London, Thousand Oaks, New Delhi: SAGE Publications; 2005. p. 274-282.

37. Stainton S. Empowerment and the architecture of rights based social policy. Journal of Intellectual Disabilities 2005; 9:289-298.

38. Menezes I, Ribeiro N, Cabral-Gouveia C. The individual and contextual impact of a school-based exhibition for AIDS prevention: a mixed methodology approach. Health Education Journal 2013; 72(3):242-253.

39. Christensen P, Prout A. Working with ethical symmetry in social research with children. Childhood 2002; 9(4):477-497.

40. Bardin L. Análise de Conteúdo. Lisboa: Edições 70; 1988.

41. Pais SC, Rodrigues M, Menezes I. Community as locus for health formal and non-formal education: the significance of ecological and collaborative research for promoting health literacy. Frontiers in Public Health Education and Promotion 2014; 2:283.

42. Nachshen J. Empowerment and families: building bridges between parents and professionals, theory and research. Journal on Development Disabilities 2004; 11(1):67-75

43. Moreira M, Albernaz LD, Sá MRC, Correia RF, Tanabe RF. Recomendações para uma linha de cuidados para crianças e adolescentes com condições crônicas complexas de saúde. Cad Saude Publica 2017; 33(11):2727-2734.

44. Morris J. Citizenship and Disabled People. London: Disability Rights Commission; 2005.

45. Ryan W. Blaming the Victim. New York: Vintage Books; 1971.

46. Kyngas H. Support network of adolescents with chronic disease: adolescents' perspective. Nursing and Health Sciences 2004; 6:287-293.

47. Grootenhuis MA, Koopman HM, Verrips EG, Vogels A, Last BF. Health-related quality of life problems of children aged 8-11 years with a chronic disease. Developmental Neurorehabilitation 2007; 10(1):27-33.

48. Pais SC. Vivência e qualidade de vida escolar, empoderamento e participação: $O$ caso das crianças e jovens com doença crónica e suas famílias [non-published thesis]. Porto; University of Porto; 2012.

Artigo apresentado em 04/12/2018

Aprovado em 01/07/2019

Versão final apresentada em 03/07/2019 